\title{
UN 공동 원조전략 회의 참석결과 보고
}

스리랑카 $\mathrm{KOICA}$ 사무소는 지난 2.28 개최된 주재 국 UN 산하 기구들의 2008 - 2012년간 원조전략 발표회에 참석하였고, 각 기구별 주요 전략 및 $\mathrm{KOICA}$ 협력사업에의 시사점 등 참석 결과는 아래 와 같음.

\section{1. 회의 개요}

- 일 시 : 2007.2.28(수), 14:30-17:30

- 장 소 : Oak Room, Cinnamon Grand

- 목 적

- UNDP, UNICEF 및 UNFPA 등 UN 산하기 관들의 2008-2012년간의 대주재국 원조전 략 발표를 통해 향후 UN측의 대주재국 원조 기본방향을 천명하고, 주요 원조공여 기관 및 주재국내 협력기관(NGO 등)의 리뷰를 통
해 개선 필요 사항 반영

- 주요 내용

- 회의 개최 목적 발표 (UNRC)

- Country Programme 발표 (UNICEF)

- Country Programme 발표 (UNFPA)

- Country Programme 발표 (UNDP)

- 토론 및 정리

- 참석자

$-\mathrm{UN}$ 측

: Mr. Frederick Lyons, UN Resident \& Humanitarian Coordinator

:Mr. Abu Selim, UNDP Country Director :Ms. JoAnne Van Gerpen, Representative UNICEF

:Ms. Lubna Baqi, Representative UNFPA 및 UN측 관계자 30 여명 
- 일본, 노르웨이, 스웨덴, 영국 등 대사관 및 원조기관 관계자 30 여명

- 인권위원회, 콜롬보대학, 여성인권위원회 등 주재국내 학계 및 $\mathrm{NGO}$ 관계자 20 여명

\section{2. 협력사업 시사점}

- 금번 UN 기관들의 2008-2012년간 원조전략 은 주재국 개발계획의 근간인 Mahinda Chintana와 Sri Lanka' s 10 Year Development Framework, Millenium Development Goals 및 UNCCA(United Nations Common Country AssessmentSri Lanka/2006.10월) 등에 바탕을 두고 수 원국과의 협의에 근거하여 작성되었음.

- UNDP 등 해당 기관은 금번 회의결과를 토대 로 최종안 도출 예정이며, 동 전략에 근거하여 2007년 말부터 2008년 이후 진행할 프로그램 계획(action plan)을 수립할 예정임.

- 동 action plan은 프로그램별 out put 달성 을 위한 세부 계획 및 예산확보/집행 계획을 포함.

- 2008-2012년간 원조전략의 각각 단위별 out put 달성을 위한 개별 프로그램은 연간 계획되고 예산 배정되며, 수정 반영됨.

- 우리 중장기 원조전략 수립 및 세부 계획 수립 시, 최소 해당년도 1 년전에 국별 중점 지원분
야 위주의 주재국 내외 환경 분석에 근거한 전 문화된 기본 전략 수립이 필요하며, 기본 전략 수립과 함께 부문별 개략적인 예산확보 및 예 산소요 계획을 사전 수립하고, 각 부문별 outcome 및 output 달성을 위한 세부 프로그 램을 연간단위로 수립, 조정해 나갈 수 있도록 해야 할 것임.

- 기본전략 수립시 부문별 사업계획을 별도로 수립하기 보다는 각 부문별 outcome과 output을 명시하고, 이의 달성을 위한 세부 사업별 프로그래밍은 연간 단위로 수원국 수 요 등을 감안하여 조정

\section{3. 기관별 주요 원조전략}

\section{가. UNICEF}

1) 부문별 예산계획

\begin{tabular}{c|c}
\hline 프로그램 & 백만불 \\
\hline 교 육 & 7.48 \\
\hline 보건/영양 & 6.82 \\
\hline 식수/위생 & 6.60 \\
\hline 아동 보호 & 7.26 \\
\hline 기획, 모니터링 및 평가 & 2.04 \\
\hline 다부문(cross-sectoral) & 3.80 \\
\hline 합 계 & 34.00
\end{tabular}

\section{2) 2008-2012년중 주요 해결 과제}

- 교육의 질적 향상과 낙제생 문제

- 차 재배 지역 등 개발 소외지역 아동들의 높은 
- 지방 및 내전 지역에서의 안전식수 및 위생시 설에 대한 접근성

- 아동학대 및 착취 근절을 위한 기반 조성

- 내전지역 아동들에 대한 위험요인(미성년 고 용 및 지뢰 등)으로부터의 보호

2만명 이상으로 추정되는 보육원 등 보호시설 아동 문제

- 내전, 분쟁상황에 적합한 프로그래밍 접근 방식

\section{3) 교육부문 지원전략}

- 아동 친화적 학교환경 구축 및 교육격차 해소

- 참여적 학습 지원

- 낙오 학생 모니터링

- 학교출석 위원회 조직

- 아동친화 학습 및 교수법에 관한 학교 기반 훈련 과정 제공

- 교육 운영자들에 대한 훈련 과정 제공

\section{4) 보건/영양 부문 지원전략}

- 아동 보호 및 급식에 있어서 지역에 기반한 접
- 임산부를 위한 특별 지원

a 모자보건 프로그램 영역에 $\mathrm{PMTCT}$ (Prevention of Mother to Child Transmission)의 통합

a 내전, 분쟁지역에서의 보건의료부문 인력 개발

5) 식수 및 위생 부문 지원전략

- 스리랑카 정부의 수자원 담당기관인 National Water Supply \& Development Board의 역 량강화를 위한 기술 지원

- 난민 재정착 지역에서의 환경친화적인 용수공 급 및 위생 설계 실행

\section{6) 아동보호 부문 지원전략}

- 아동권리보호협약(Convention of Rights of Child)의 이행을 위한 주요 법안 개혁 지원

- 보호시설 아동들을 가족에게 돌려 보내기 위 한 정부측 노력 지원

- 지역 단위 정부 및 민간 차원의 아동보호 시설 
에 대한 지원 확대

- 무장단체들의 소년병 징집에 대한 방지 및 석 방 옹호

- 아동권리 침해에 대한 모니터링 및 보고

\section{7) 중점 지원지역 및 고려 사항}

- 개발 소외지역인 차재배 등 농장지역(모네라 갈라, 바둘라, 라트나푸라, 누와라엘리야 등)

- 북동부 내전, 분쟁지역

- 중점 고려사항 : 인권, 성폭력, 농장지역 개발

나. UNFPA

1) 부문별 예산계획

\begin{tabular}{c|c}
\hline 프로그램 & 백만불 \\
\hline 생식보건 & 10.00 \\
\hline 성평등 & 4.75 \\
\hline 인구와 개발 & 0.50 \\
\hline 프로그램 조정 및 지원 & 0.75 \\
\hline 합 계 & 16.00 \\
\hline
\end{tabular}

\section{2) 생식보건 부문 지원전략}

- 종합적인 생식보건 서비스의 질적 향상 및 수 요충족을 위한 국가 보건 시스템 역량강화
- 생식보건 시스템의 질적 보장 강화

- 생식보건 부문 의료인력의 기능 향상

- 보건부문에 있어서 관리역량 강화

- 성폭력에 대처하는 보건의료 부문 역량 강화

- 분쟁지역 및 개발 소외지역에서의 생식보건 부문 서비스의 유효성 및 접근성 증대

- 긴급구호 및 인도적지원 분야

- 언제든지 공급가능한 생식보건 물품 완충 재고량(buffer stock) 확대

- 생식보건 이동진료 서비스 확대

- 수혜 소외지역에 숙련된 보건의료 봉사자 배치

- 중기지원 및 지역역량 강화

- 생식보건 분야 서비스 개선을 위한 역내 제 도적 기제 강화

- 의료규정 및 표준의 채택, 의료인력의 역량 강화

- 지역사회 수준에서의 보건의료 증진 활동 장려

- 생식보건 데이터의 접근성 및 질적 개선

- 여성, 청년층의 성전염성 질병 및 HIV/AIDS 예방

- 콘돔 사용 장려

- 생식보건 프로그램과 성전염성 질병 및 $\mathrm{HIV} / \mathrm{AIDS}$ 프로그램 간의 연계 강화

- 성산업 종사 여성, 비정식 고용직, 비진학 청 년층, 이주여성 노동자 등 소외 계층을 위한 
사업 확대

\section{3) 젠더부문 지원전략}

- 성폭력 예방 및 대처를 위한 정부, 비정부, 공 동체 기관의 역량 강화

- 가정폭력법 및 행동강령의 실행 지원

- NGO를 통한 "여성쉼터” 설립 지원

- 성폭력 예방을 위한 지역사회 역량 강화

- 성폭력 근절로의 변화를 위한 프로그램에 남 성의 참여 강화

- 여성과 소녀의 권리수호에 있어 국가 차원의 책임성을 강조하는 정부역량 및 제도적 기제 강화

- 여성관련 부처 및 위원회의 정책수립, 프로 그램기획 및 홍보 등 역량강화 지원

- 여성권리 보호를 위한 다양한 메카니즘 지원

- 여성권리 수호를 위한 지역사회 역량 강화

- 평화구축 과정에 있어서의 여성의 참여역량 강화

\section{4) 인구와 개발부문 지원전략}

- 성별, 연령별 분화된 인구데이터의 유효성 및 활용도 증대

- 인구 센서스에 있어서 성별분화 작업 지원

- 가정폭력 사례에 대한 전국적인 연구 수행

- 인구 관련 정보의 활용역량 구축

- 성인지적 분석, 기획 및 예산수립에 있어서 의 제도적 역량 강화

- MDGs 달성목표 측정에 있어서 성인지적 접 근방식에 의한 제도적 역량 강화

\section{다. UNDP}

1) 부문별 예산계획

\begin{tabular}{c|c}
\hline 프로그램 & 백만불 \\
\hline 빈곤감축 & 25.2 \\
\hline 거버넌스 & 11.75 \\
\hline 평화구축 & 34.40 \\
\hline 젠 더 & 0.55 \\
\hline 합 계 & 71.90 \\
\hline
\end{tabular}




\section{2) 빈곤감축 분야}

\begin{tabular}{l|l}
\hline \multicolumn{1}{c|}{ Country Programme Outcomes } & \multicolumn{1}{c}{ Country Programme Outputs } \\
\hline \multirow{2}{*}{ 1. 빈곤경감을 위한 공평하고 포괄적인 국가 정책 } & a.MDG에 근거한 개발정책 \\
\cline { 2 - 2 } & b.MDG 데이터의 취합 및 분석 \\
\cline { 2 - 2 } & c. MDG 달성율 보고 \\
2. 개발소외 지역에서의 질적으로 향상된 사회경제 & a. 플랜테이션(차 재배지역 등) 지역사회를 위한 다부문적 \\
서비스에의 공평한 접근 & 국가 행동강령의 실행 \\
\cline { 2 - 3 } & b. - MDGs 달성을 위한 공공서비스 전달 및 \\
& - 천재, 인재에 대한 대처 역량에 있어서의 지역사회 역량 개발 \\
\hline \multirow{2}{*}{ 3. 취약계층을 위한 지속가능하고 향상된 } & a. 기능개발, 생계기회 및 시장에의 접근성 향상을 위한 \\
수준의 사회경제 개발 & 지역사회 개발 프로젝트 \\
\cline { 2 - 3 } & b. 천연자원 관리 및 재활용에너지 활용을 위한 지역사회 역량 개발 \\
\hline
\end{tabular}

\section{3) 거버넌스 분야}

\begin{tabular}{|c|c|}
\hline Country Programme Outcomes & Country Programme Outputs \\
\hline \multirow{2}{*}{$\begin{array}{l}\text { 1. 기능강화되고 독립적인 법적/제도적 기틀을 통한 } \\
\text { 거버넌스 향상 }\end{array}$} & a. 국회 감독 체제의 강화 \\
\hline & b. 독립적인 감독위원회 기능 강화 \\
\hline $\begin{array}{l}\text { 2. 지방 조직구조의 사법 및 서비스 전달 역량에서의 } \\
\text { 접근성 향상 }\end{array}$ & $\begin{array}{l}\text { a. 사법과 배상 기제에 있어서 공평한 접근기회를 제공하기 위한 } \\
\text { 법률적, 사법적 서비스 전달 기관들의 역량 강화 } \\
\text { b. 공공부문 서비스의 효율적 전달을 위한 지방정부 및 기구의 역량 강화 }\end{array}$ \\
\hline 3. 개인과 공동체의 역량 강화를 통한 참여적 의사결정 & $\begin{array}{l}\text { a. 모든 수준에서의 인권 및 사법 메카니즘에 대한 옹호 및 대중 인식 제고 } \\
\text { b. 의사결정 과정에서 국민참여 증진을 위한 지역별 대표기구의 역량 강화 }\end{array}$ \\
\hline \multirow[t]{2}{*}{ 4. 보다 효과적, 대응적인 개발정책 및 프로그램 } & $\begin{array}{l}\text { a. 국가/지역 수준에서의 통합적 정보관리 시스템을 통한 } \\
\text { 성과지향의 모니터링 및 평가 강화 }\end{array}$ \\
\hline & b. 모든 정보관리 시스템의 상호작용을 통한 원조 조정 기제 강화 \\
\hline
\end{tabular}

\section{4) 평화구축 분야}

\begin{tabular}{l|l}
\hline \multicolumn{1}{c|}{ Country Programme Outcomes } & \multicolumn{1}{c}{ Country Programme Outputs } \\
\hline \multirow{2}{*}{ 1. 분쟁지역에서의 사회경제 개발을 위한 공정성 개선 } & $\begin{array}{l}\text { a. UNDP의 지역별 현장 사무소 네트워크를 통한 분쟁지역 } \\
\text { 지역사회를 위한 지역기반 부흥 및 복구 프로그램 }\end{array}$ \\
\cline { 2 - 2 } & b. 지뢰제거 사업을 통한 생계 및 경제활동의 조기 복구 \\
\hline \multirow{2}{*}{ 2. 평화적 공존을 위한 전국적 합의 } & a. 평화 및 화해를 위한 정부 및 시민사회 기구들의 역량강화 지원 \\
\hline \multirow{2}{*}{ ․ 분쟁 방지, 인권증진 및 인도적 법안의 존중 } & a. 공용어 정책의 전개 및 실행 \\
\cline { 2 - 2 } & b. 인권보호를 위한 오타와 협약 등의 국제법 준수 지원 \\
\hline
\end{tabular}




\section{5) 젠더 분야}

\begin{tabular}{l|l}
\hline \multicolumn{1}{c|}{ Country Programme Outcomes } & \multicolumn{1}{c}{ Country Programme Outputs } \\
\hline \multirow{2}{*}{ 1. 분쟁지역에서의 사회경제 개발을 위한 공정성 개선 } & $\begin{array}{l}\text { a. UNDP의 지역별 현장 사무소 네트워크를 통한 분쟁지역 } \\
\text { 지역사회를 위한 지역기반 부흥 및 복구 프로그램 }\end{array}$ \\
\cline { 2 - 2 } & b. 지뢰제거 사업을 통한 생계 및 경제활동의 조기 복구 \\
\hline 2. 평화적 공존을 위한 전국적 합의 & a. 평화 및 화해를 위한 정부 및 시민사회 기구들의 역량강화 지원 \\
\hline \multirow{2}{*}{ 3. 분쟁 방지, 인권증진 및 인도적 법안의 존중 } & a. 공용어 정책의 전개 및 실행 \\
\cline { 2 - 3 } & b. 인권보호를 위한 오타와 협약 등의 국제법 준수 지원 \\
\hline
\end{tabular}

※ 빈곤감축, 거버넌스, 평화구축 등 분야에 cross-cutting 이슈로서 젠더부문에 대한 고려는 이미 반영 되었으나, 이와는 별도로 수혜자로서의 여성에 중점을 둔 프로그램을 별도로 기획.

[자료 : 주스리랑카민주사회주의대사관] 